\title{
Changes in Follicular CD4+ T Helper Cells as a Marker for Evaluating Disease Progression in the Competition between HIV and Host Immunity
}

\author{
Xiaolei Wang, Widade Ziani and Huanbin Xu* \\ Tulane National Primate Research Center, Tulane University School of Medicine, Covington, LA, USA
}

Follicular CD4+ Thelper (TFH) cells interact with B cells in follicular germinal centers and play a prominent role in promoting effective humoral immune responses to pathogens, providing help for B cell development and antibody affinity maturation. Recent studies indicate TFH cells are expanded in HIV/SIV chronic infection, or depleted in terminal stages of disease, yet relatively maintained in elite controllers when compared with unin-

OPEN ACCESS

Edited by:

Smita S. Iyer,

Emory University, USA

Reviewed by:

Anthony Jaworowski,

Burnet Institute, Australia

Mariangela Cavarelli,

CEA, France

*Correspondence:

Huanbin Xu

hxu@tulane.edu

Specialty section:

This article was submitted

to HIV and AIDS,

a section of the journal

Frontiers in Immunology

Received: 13 July 2016 Accepted: 19 October 2016 Published: 31 October 2016

Citation:

Wang $X$, Ziani $W$ and $X U \mathrm{H}$ (2016) Changes in Follicular CD4+

T Helper Cells as a Marker

for Evaluating Disease Progression

in the Competition between

HIV and Host Immunity.

Front. Immunol. 7:474.

doi: 10.3389/fimmu.2016.00474 fected controls. A better understanding of the mechanisms behind these immunologic abnormalities may lead to more effective vaccination and therapeutic strategies. Here, we review recent findings of TFH cells in HIV/SIV infection and discuss the correlation of changes and function of TFH cells with host immunity. Dysregulation or depletion of CD4+ TFH cells likely plays a major role in the inability of HIV-infected patients to mount effective immune responses.

Keywords: follicular CD4 T helper cells, HIV, TFH cells, SIV, immunity

\section{INTRODUCTION}

$\mathrm{T}$ follicular helper $\mathrm{T}$ cells are specialized CD4+ $\mathrm{T}$ cells that promote antigen-specific B cell development and maturation. TFH cells represent a heterogeneous cell population including non-GC (germinal center) and GC TFH cells (1-4). Non-GC TFH cells include circulating TFH cells and "immature" PD- $1^{\mathrm{INT}}$ TFH cell precursors in lymph nodes, the latter are mostly distributed in interfollicular zones where their differentiation to fully functional GC TFH cells is initiated $(5,6)$. However, non-GC TFH cells still possess some B-cell helper functions, although they are less efficient than GC TFH cells (7-10). The GC is the crucial niche for the optimal expansion and survival of CD4+ TFH cells and for processes such as somatic hypermutation and selection of high-affinity B cells (11). Mature GC TFH cells (PD-1 ${ }^{\mathrm{HIGH}}$ CXCR5+CD4+ $\mathrm{T}$ cells) are only found in GCs of organized lymphoid tissues such as gut associated lymphoid tissues (GALT), lymph nodes, spleen, and tonsils and are rare or absent in peripheral blood (10). Immature TFH migrate into GCs where they mature and co-localize with follicular dendritic cells (FDC) and B cells $(12,13)$. Mature GC TFH cells interact with GC B cells by stable cell-to-cell contacts or/and cytokine production such as IL-21 and promote development and maturation of antigen-specific B cells or antibody-secreting plasma cells, thereby ensuring effective, longterm humoral immune responses $(14,15)$. Mature TFH cells express high levels of CXCR5, PD-1, SLAM-associated protein (SAP), GL7, ICOS, and transcriptional factor Bcl-6 $(8,16)$. 
Although peanut agglutinin (PNA) staining is often used to define GC-derived TFH cells in mice and macaques (17), we have found it not specific for TFH in macaque lymph nodes by confocal image analysis. Definitive identification of GC TFH cells in lymphoid tissues is best demonstrated by CXCR5+ PD- $1^{\mathrm{HIGH}}$ expression on CD4+ T cells by immunohistochemistry in situ (10, 18-20). Interestingly, PD-1 has also been described as a potent $\mathrm{T}$ cell inhibitory receptor of CD8+ T cells associated with T-cell "exhaustion" $(21,22)$; however, its high expression on GC CD4+ TFH cells is involved in the regulation and survival of GC B cells through interaction with its ligands expressed on the latter $(13,23)$, thus PD-1 is a critical functional molecule for GC TFH cells.

\section{ARCHITECTURAL DAMAGE OF LYMPHOID TISSUE IN HIV INFECTION}

In early HIV/SIV infection, marked lymphoid follicular hyperplasia and dysplasia are observed, and, eventually, massive depletion of CD4 T cells occurs in chronic stages of infection stage. With disease progression, there is generalized lymphoid destruction, as indicated by reduction in GC size and number, loss of the stromal fibroblastic reticular cell (FRC) network, emergence of fibrosis, collagen deposition, and follicular involution (24-27). These features have been shown to gradually result in an inability to mediate antibody production and antigen-specific $\mathrm{T}$ cell responses (28-30). Absence of TFH also leads to B-cell apoptosis during priming, thereby preventing $\mathrm{B}$ cell differentiation and maturation (31). Thus, loss of CD4+ GC TFH cells in lymphoid tissues is believed to be a major factor in the impairment of $\mathrm{B}$ cell responses in HIV infection.

\section{INFECTION OF GC TFH AND ESTABLISHMENT OF PERSISTENT RESERVOIRS IN LYMPHOID TISSUES IN HIV/SIV}

Organized lymphoid tissues are the major sites for HIV replication and latency (32-34). These and other studies indicate follicular CD4+ T cells in GC in particular may be the major persistent reservoir in patients on ART, which may be directly related to the impairment of effective antibody responses (35). Infected TFH cells residing within these GC "sanctuaries" might be shielded from virus-specific cytotoxic T cell (CTL) responses, allowing them to persist in GC, even when plasma viral loads are completely suppressed by ART (36), p. 1562 (19, 34, 37-42). Further, lower concentrations of antiviral drugs have been demonstrated in lymphoid tissues compared to blood, which may contribute to the persistent viral replication and latent infection in these tissues (43).

Mature GC TFH cells are clearly infected in $\operatorname{HIV} / \operatorname{SIV}(12,39)$. We have found that extracellular CCR5 is predominantly expressed on $\mathrm{PD}-1^{\mathrm{INT}} \mathrm{TFH}$ cell precursors, but downregulated on PD- ${ }^{\mathrm{HIGH}}$ GC TFH cells in lymph nodes of uninfected or SIV-infected macaques (12). Since GC TFH cells also do not express other known alternative SIV co-receptors (CXCR6 and
GPR15) (39), we have proposed that TFH precursors in the mantle zones or/and T-cell zones might be the major targets for direct viral infection. These immature TFH cell precursors (PD-1 $1^{\text {Neg/INT }}$ CD4+ T cells) in lymph nodes from normal macaques are able to differentiate into mature PD-1 $1^{\mathrm{HIGH}} \mathrm{GC}$ TFH cells when stimulated with proinflammatory cytokines, such as IL-6 and IL-21, in vitro. When TFH cell precursors, sorted from SIV-infected macaques, differentiate into GC TFH cells stimulated by these cytokines, SIV DNA is detectable in these GC TFH cells, supporting the hypothesis that virus-infected GC TFH cells may develop from migrating TFH precursors that are infected in the non-GC regions, where they express CCR5 (12). Further, our data indicate that SIV RNA/SIV p28 protein levels are relatively lower in GC regions compared with the cortex, paracortex, and medulla of SIV-infected macaques, whereas higher levels of SIV proviral DNA and, to some extent, SIV RNA in GC TFH cells are still detected, suggesting that GC TFH cells are both latently and productively infected by HIV/SIV $(12,34)$.

It is well known that abundant cytokines and chemokines are induced as proinflammatory responses to viral infection in acute and chronic HIV/SIV infection (44). Persistently high levels of cytokines such as IL-6, IL-21, and IFN- $\gamma$ in lymph nodes lead to abnormal accumulations of GC TFH cells $(5,45)$. In addition, persistent antigen presentation may promote $\mathrm{GC}$ TFH cell development $(4,46,47)$, and even redirect Th1 cells to differentiate into TFH cells during persistent viral infections such as LCMV infection (37). Recent studies indicate the viral reservoir is rapidly established during the "eclipse" phase, prior to SIV viremia (48), and this may be associated with increased cell activation, aberrant TFH cell differentiation, and proinflammatory responses at this stage. Together, these findings suggest TFH cell precursors are infected as they migrate toward GCs, where mature GC TFH cells display productive and latent infection. Thus, persistent HIV/SIV replication and infection and chronic systemic immune activation (49) accompanied with elevated proinflammatory cytokine responses, and persistent antigen stimulation, drives TFH precursor activation, migration to and infection within the T-cell zones, and subsequent migration into the GC where GC TFH fully mature, lose CCR5 expression, and persist as productively and latently infected cellular reservoirs for HIV/SIV infection. Finally, these GC TFH cells may persist in what may be an immune privileged site, which may not be accessible to ART or antiviral cellular responses. Eliminating virus from these "sanctuary" sites may be a significant hurdle for vaccination and cure strategies.

\section{CHANGES IN TFH CELLS DEPEND ON THE CONSEQUENCE OF HIV INFECTION AND HOST IMMUNITY}

Previous studies indicate that TFH cells in lymph nodes are expanded in HIV- or SIV-infected individuals $(17,50)$, whereas others reported that TFH cell are significantly depleted during HIV infection in peripheral blood and spleen (13, 51-54). By examining large numbers of SIV-infected macaques, our studies show that GC TFH cells are significantly depleted by 
$14 \mathrm{dpi}$, and then gradually accumulate in the chronic stage of infection. However, we do not find consistent expansions of GC TFH in all chronically SIV-infected macaques. Further analysis indicate that GC TFH cells accumulate in chronic SIV/HIV infection in adult animals infected with pathogenic SIVmac (asymptomatic chronic), whereas there were little to no changes in these cells in animals inoculated with less pathogenic viruses or those associated with control of viremia (i.e., Mamu- $A^{\star} 01+$ rhesus macaques) when compared with uninfected macaques. Of note, adult animals with AIDS (opportunistic infections or neoplasia) show marked losses of GC TFH cells and higher levels of turnover, activation, and apoptosis correlating with chronic inflammation (13). Effective immune responses ultimately resolve viral infections, whereas immune deficiencies fail to

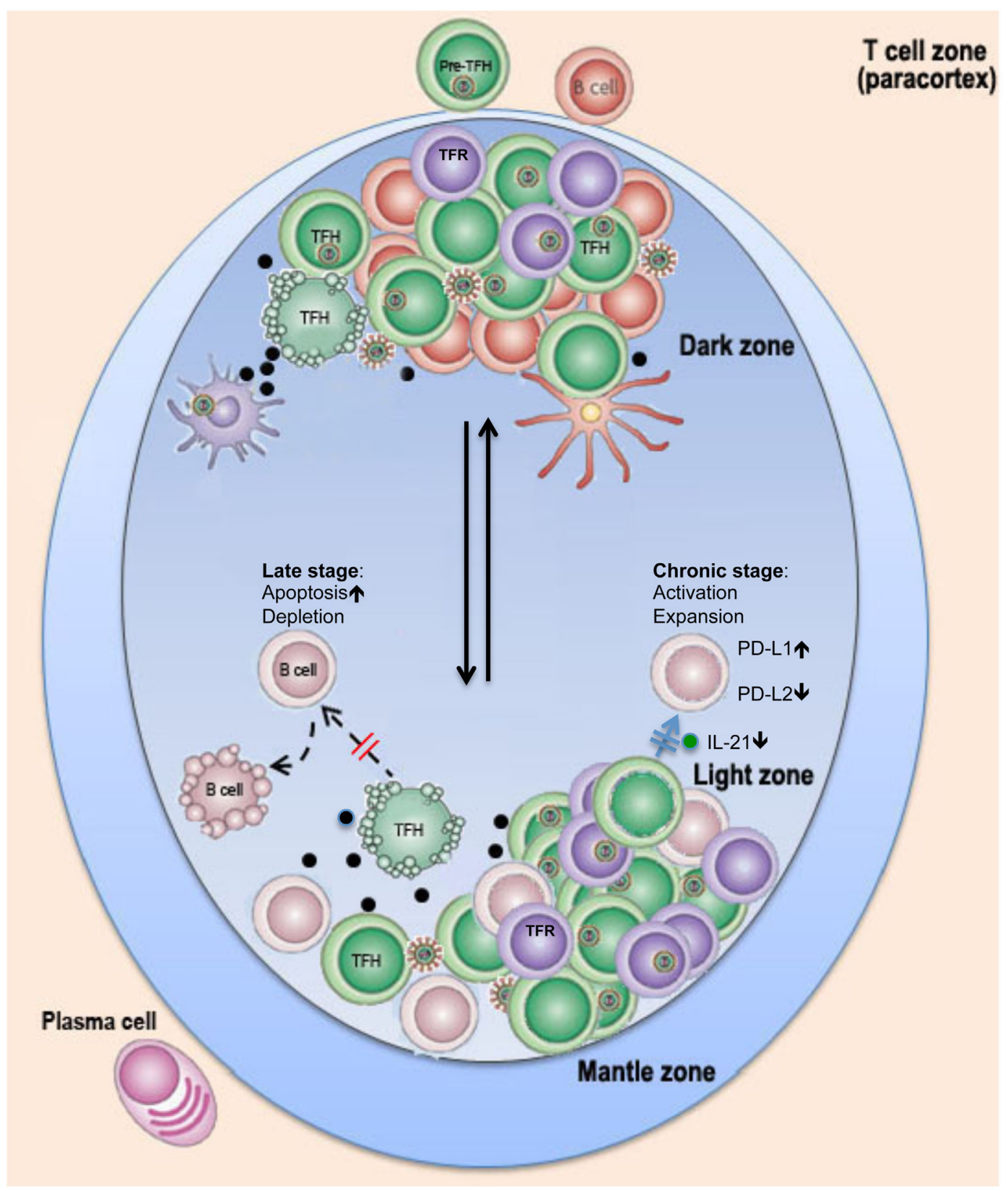

FIGURE 1 | Schematic of possible changes in TFH cells in lymph nodes in pathogenic HIV infection. Rapid flux of GC B cells between the dark and light zones facilitates several iterative rounds of mutation and selection, resulting in the generation of memory B cells and plasma cells with high-affinity antibodies. In HIV/ SIV infection, follicular dendritic cells (FDC) in lymph nodes are exposed/infected during HIV infection and secrete high levels of proinflammatory cytokines, which, in combination with viral antigens, promote GC TFH and TFR cell expansion in chronic stage or ultimate depletion of GC TFH cells by direct lysis or/and apoptosis at later stages. Loss of help or dysfunction of TFH cells leads to impairment of B cell function and germinal center reaction and prevents long-term effective humoral immune responses to HIV infection. 
clear virus and lead to persistent infections $(22,55)$. Ours and other studies demonstrate GC TFH cells are enriched in lymph nodes of chronically SIV-infected animals, accompanied by reductions of $\mathrm{PD}-1^{\mathrm{NEG} / \mathrm{INT}} \mathrm{CD} 4+\mathrm{T}$ cells and increased levels of dysfunctional PD-1+ CD8+ T cells with disease progression $(13,18)$. In comparison, percentages of PD-1+ CD8+ T cells are lower in uninfected or SHIV-infected cohorts. Finally, untreated infants infected with HIV maintain higher viremia throughout infection and rapidly progress to $\operatorname{AIDS}(56,57)$ which emerging evidence suggests may be due to inadequate $\mathrm{TFH}$ responses. Combined, these findings suggest persistent SIV infection leads to exhaustion of TFH precursors and abnormal accumulation or ultimate depletion of GC TFH cells, concomitant with increased dysfunctional CD8+ T cells, leading to eventual disease progression. As compensatory responses, GC TFH cells excessively differentiate, and remain productively and/or latently infected, until they are depleted in terminal AIDS. Together, data suggest that changes in GC TFH cell number and function closely parallel stages in the progression of disease.

\section{DYSFUNCTION OF TFH CELLS}

Constitutive and high expression of PD-1 on GC TFH cells promotes IgG production possibly through PD-1/PD-L2 interactions, suggesting $\mathrm{PD}-1$ regulates $\mathrm{B}$-cell functions in GC via direct cell-to-cell interaction $(10,13)$. Other reports indicate engagement of PD-1 on TFH cells inhibits IL-21 production in HIV infection, resulting in inadequate B-cell help indirectly through the PD-1/PD-L1 pathway (38), which is supported by decreased levels of IL-21 production in TFH cells in chronic SIV infection. Thus, PD-L1 upregulation and PD-L2 downregulation on B cells, which are observed in chronic HIV/SIV infection, might result

\section{REFERENCES}

1. Linterman MA, Liston A, Vinuesa CG. T-follicular helper cell differentiation and the co-option of this pathway by non-helper cells. Immunol Rev (2012) 247:143-59. doi:10.1111/j.1600-065X.2012.01121.x

2. Shulman Z, Gitlin AD, Targ S, Jankovic M, Pasqual G, Nussenzweig MC, et al. $\mathrm{T}$ follicular helper cell dynamics in germinal centers. Science (2013) 341:673-7. doi:10.1126/science.1241680

3. Xu H, Li X, Liu D, Li J, Zhang X, Chen X, et al. Follicular T-helper cell recruitment governed by bystander B cells and ICOS-driven motility. Nature (2013) 496:523-7. doi:10.1038/nature12058

4. Barnett LG, Simkins HM, Barnett BE, Korn LL, Johnson AL, Wherry EJ, et al. B cell antigen presentation in the initiation of follicular helper T cell and germinal center differentiation. J Immunol (2014) 192:3607-17. doi:10.4049/ jimmunol.1301284

5. Suto A, Kashiwakuma D, Kagami S, Hirose K, Watanabe N, Yokote K, et al. Development and characterization of IL-21-producing CD4+ T cells. J Exp Med (2008) 205:1369-79. doi:10.1084/jem.20072057

6. Kerfoot SM, Yaari G, Patel JR, Johnson KL, Gonzalez DG, Kleinstein SH, et al. Germinal center B cell and T follicular helper cell development initiates in the interfollicular zone. Immunity (2011) 34:947-60. doi:10.1016/ j.immuni.2011.03.024

7. Yu D, Vinuesa CG. The elusive identity of $\mathrm{T}$ follicular helper cells. Trends Immunol (2010) 31:377-83. doi:10.1016/j.it.2010.07.001

8. Crotty S. Follicular helper CD4 T cells (TFH). Annu Rev Immunol (2011) 29:621-63. doi:10.1146/annurev-immunol-031210-101400

9. Wang $\mathrm{C}$, Hillsamer P, Kim CH. Phenotype, effector function, and tissue localization of $\mathrm{PD}$-1-expressing human follicular helper T cell subsets. BMC Immunol (2011) 12:53. doi:10.1186/1471-2172-12-53 in impairments of B-cell function and antibody production in chronic HIV/SIV infection (13). B-cell follicles contain a novel subset of regulatory $\mathrm{T}$ cell (Treg), termed follicular regulatory T cells (TFR), which express CXCR5 and repress effective GC responses through interactions with TFH cells (58-60). Recent studies reported that TFR cells are expanded and impair TFH functions in HIV/SIV infection $(61,62)$. As discussed above, factors such as architectural disruption of lymphoid tissues, aberrant TFR regulation, dysregulation of B cells, TFH cell infection, and eventual TFH depletion in AIDS are all fundamental contributors to the impairment of functional B-cell responses and antibody production during HIV/SIV infections (Figure 1). Antiviral therapy, in combination with anti-inflammatory agents and perhaps inhibitors of cell differentiation, could be considered as an adjunct to early intervention strategy to reduce viral reservoir size and lymphoid tissue disruption and improve humoral immune responses in $\mathrm{HIV}$-infected patients.

\section{AUTHOR CONTRIBUTIONS}

$\mathrm{HX}$ wrote and revised the manuscript; XW and WZ assisted with manuscript preparation.

\section{FUNDING}

This work was supported by NIH grants R01 DE025432, R01 AI099795, R01 AI084793, U19 AI076981, the National Center for Research Resources, and the Office of Research Infrastructure Programs (ORIP) of the National Institutes of Health through grant no. OD011104-51. The funders had no role in study design, data collection and analysis, decision to publish, or preparation of the manuscript.

10. Xu H, Wang X, Lackner AA, Veazey RS. PD-1(HIGH) follicular CD4 T helper cell subsets residing in lymph node germinal centers correlate with B cell maturation and IgG production in rhesus macaques. Front Immunol (2014) 5:85. doi:10.3389/fimmu.2014.00085

11. MacLennan IC. Germinal centers. Annu Rev Immunol (1994) 12:117-39. doi:10.1146/annurev.iy.12.040194.001001

12. Xu H, Wang X, Malam N, Aye PP, Alvarez X, Lackner AA, et al. Persistent simian immunodeficiency virus infection drives differentiation, aberrant accumulation, and latent infection of germinal center follicular $\mathrm{T}$ helper cells. J Virol (2015) 90:1578-87. doi:10.1128/JVI.02471-15

13. Xu H, Wang X, Malam N, Lackner AA, Veazey RS. Persistent simian immunodeficiency virus infection causes ultimate depletion of follicular Th cells in AIDS. J Immunol (2015) 195:4351-7. doi:10.4049/jimmunol.1501273

14. Zotos D, Coquet JM, Zhang Y, Light A, D'costa K, Kallies A, et al. IL-21 regulates germinal center $\mathrm{B}$ cell differentiation and proliferation through a B cell-intrinsic mechanism. J Exp Med (2010) 207:365-78. doi:10.1084/ jem.20091777

15. King C, Sprent J. Emerging cellular networks for regulation of T follicular helper cells. Trends Immunol (2012) 33:59-65. doi:10.1016/j.it.2011.11.006

16. Johnston RJ, Poholek AC, Ditoro D, Yusuf I, Eto D, Barnett B, et al. Bcl6 and Blimp-1 are reciprocal and antagonistic regulators of $\mathrm{T}$ follicular helper cell differentiation. Science (2009) 325:1006-10. doi:10.1126/science. 1175870

17. Petrovas C, Yamamoto T, Gerner MY, Boswell KL, Wloka K, Smith EC, et al. CD4 $\mathrm{T}$ follicular helper cell dynamics during SIV infection. J Clin Invest (2012) 122:3281-94. doi:10.1172/JCI63039

18. Mylvaganam GH, Velu V, Hong JJ, Sadagopal S, Kwa S, Basu R, et al Diminished viral control during simian immunodeficiency virus infection is associated with aberrant PD-1hi CD4 T cell enrichment in the lymphoid 
follicles of the rectal mucosa. J Immunol (2014) 193(9):4527-36. doi:10.4049/ jimmunol.1401222

19. Fukazawa Y, Lum R, Okoye AA, Park H, Matsuda K, Bae JY, et al. B cell follicle sanctuary permits persistent productive simian immunodeficiency virus infection in elite controllers. Nat Med (2015) 21:132-9. doi:10.1038/ nm. 3781

20. Iyer SS, Gangadhara S, Victor B, Gomez R, Basu R, Hong JJ, et al. Codelivery of envelope protein in alum with MVA vaccine induces CXCR3-biased CXCR5+ and CXCR5- CD4 T cell responses in rhesus macaques. J Immunol (2015) 195:994-1005. doi:10.4049/jimmunol.1500083

21. Blackburn SD, Shin H, Haining WN, Zou T, Workman CJ, Polley A, et al. Coregulation of CD8+ T cell exhaustion by multiple inhibitory receptors during chronic viral infection. Nat Immunol (2009) 10:29-37. doi:10.1038/ ni. 1679

22. Xu H, Wang X, Pahar B, Moroney-Rasmussen T, Alvarez X, Lackner AA, et al. Increased B7-H1 expression on dendritic cells correlates with programmed death 1 expression on $\mathrm{T}$ cells in simian immunodeficiency virus-infected macaques and may contribute to $\mathrm{T}$ cell dysfunction and disease progression. J Immunol (2010) 185:7340-8. doi:10.4049/jimmunol. 1001642

23. Good-Jacobson KL, Szumilas CG, Chen L, Sharpe AH, Tomayko MM, Shlomchik MJ. PD-1 regulates germinal center B cell survival and the formation and affinity of long-lived plasma cells. Nat Immunol (2010) 11:535-42. doi:10.1038/ni.1877

24. Chalifoux LV, King NW, Letvin NL. Morphologic changes in lymph nodes of macaques with an immunodeficiency syndrome. Lab Invest (1984) 51:22-6.

25. Schacker TW, Brenchley JM, Beilman GJ, Reilly C, Pambuccian SE, Taylor J, et al. Lymphatic tissue fibrosis is associated with reduced numbers of naive $\mathrm{CD} 4+\mathrm{T}$ cells in human immunodeficiency virus type 1 infection. Clin Vaccine Immunol (2006) 13:556-60. doi:10.1128/CVI.13.5.556-560.2006

26. Zeng M, Haase AT, Schacker TW. Lymphoid tissue structure and HIV-1 infection: life or death for T cells. Trends Immunol (2012) 33:306-14. doi:10.1016/j. it.2012.04.002

27. Estes JD. Pathobiology of HIV/SIV-associated changes in secondary lymphoid tissues. Immunol Rev (2013) 254:65-77. doi:10.1111/imr.12070

28. Fauci AS. Multifactorial nature of human immunodeficiency virus disease: implications for therapy. Science (1993) 262:1011-8. doi:10.1126/science. 8235617

29. Schacker TW, Nguyen PL, Martinez E, Reilly C, Gatell JM, Horban A, et al. Persistent abnormalities in lymphoid tissues of human immunodeficiency virus-infected patients successfully treated with highly active antiretroviral therapy. J Infect Dis (2002) 186:1092-7. doi:10.1086/343802

30. Hong JJ, Amancha PK, Rogers KA, Courtney CL, Havenar-Daughton C, Crotty S, et al. Early lymphoid responses and germinal center formation correlate with lower viral load set points and better prognosis of simian immunodeficiency virus infection. JImmunol (2014) 193:797-806. doi:10.4049/ jimmunol.1400749

31. Reinhardt RL, Liang HE, Locksley RM. Cytokine-secreting follicular T cells shape the antibody repertoire. Nat Immunol (2009) 10:385-93. doi:10.1038/ ni. 1715

32. Brenchley JM, Vinton C, Tabb B, Hao XP, Connick E, Paiardini M, et al. Differential infection patterns of CD4+ T cells and lymphoid tissue viral burden distinguish progressive and nonprogressive lentiviral infections. Blood (2012) 120:4172-81. doi:10.1182/blood-2012-06-437608

33. Horiike M, Iwami S, Kodama M, Sato A, Watanabe Y, Yasui M, et al. Lymph nodes harbor viral reservoirs that cause rebound of plasma viremia in SIV-infected macaques upon cessation of combined antiretroviral therapy. Virology (2012) 423:107-18. doi:10.1016/j.virol.2011.11.024

34. Perreau M, Savoye AL, De Crignis E, Corpataux JM, Cubas R, Haddad EK, et al. Follicular helper T cells serve as the major CD4 T cell compartment for HIV-1 infection, replication, and production. J Exp Med (2013) 210:143-56. doi:10.1084/jem.20121932

35. Douek DC, Brenchley JM, Betts MR, Ambrozak DR, Hill BJ, Okamoto Y, et al. HIV preferentially infects HIV-specific CD4+ T cells. Nature (2002) 417:95-8. doi:10.1038/417095a

36. Connick E, Mattila T, Folkvord JM, Schlichtemeier R, Meditz AL, Ray MG, et al. CTL fail to accumulate at sites of HIV-1 replication in lymphoid tissue. J Immunol (2007) 178:6975-83.
37. Fahey LM, Wilson EB, Elsaesser H, Fistonich CD, Mcgavern DB, Brooks DG. Viral persistence redirects $\mathrm{CD} 4 \mathrm{~T}$ cell differentiation toward $\mathrm{T}$ follicular helper cells. J Exp Med (2011) 208:987-99. doi:10.1084/jem.20101773

38. Cubas RA, Mudd JC, Savoye AL, Perreau M, Van Grevenynghe J, Metcalf T, et al. Inadequate $\mathrm{T}$ follicular cell help impairs B cell immunity during HIV infection. Nat Med (2013) 19:494-9. doi:10.1038/nm.3109

39. Xu Y, Weatherall C, Bailey M, Alcantara S, De Rose R, Estaquier J, et al. Simian immunodeficiency virus infects follicular helper CD4 T cells in lymphoid tissues during pathogenic infection of pigtail macaques. J Virol (2013) 87:3760-73. doi:10.1128/JVI.02497-12

40. Connick E, Folkvord JM, Lind KT, Rakasz EG, Miles B, Wilson NA, et al. Compartmentalization of simian immunodeficiency virus replication within secondary lymphoid tissues of rhesus macaques is linked to disease stage and inversely related to localization of virus-specific CTL. J Immunol (2014) 193:5613-25. doi:10.4049/jimmunol.1401161

41. Banga R, Procopio FA, Noto A, Pollakis G, Cavassini M, Ohmiti K, et al. PD-1(+) and follicular helper T cells are responsible for persistent HIV-1 transcription in treated aviremic individuals. Nat Med (2016) 22:754-61. doi: $10.1038 / \mathrm{nm} .4113$

42. Vargas-Inchaustegui DA, Demers A, Shaw JM, Kang G, Ball D, Tuero I, et al. Vaccine induction of lymph node-resident simian immunodeficiency virus Env-specific T follicular helper cells in rhesus macaques. J Immunol (2016) 196(4):1700-10. doi:10.4049/jimmunol.1502137

43. Fletcher CV, Staskus K, Wietgrefe SW, Rothenberger M, Reilly C, Chipman JG, et al. Persistent HIV-1 replication is associated with lower antiretroviral drug concentrations in lymphatic tissues. Proc Natl Acad Sci U S A (2014) 111:2307-12. doi:10.1073/pnas.1318249111

44. Xu H, Wang X, Morici LA, Pahar B, Veazey RS. Early divergent host responses in SHIVsf162P3 and SIVmac251 infected macaques correlate with control of viremia. PLoS One (2011) 6:e17965. doi:10.1371/journal. pone. 0017965

45. Lee SK, Silva DG, Martin JL, Pratama A, Hu X, Chang PP, et al. Interferongamma excess leads to pathogenic accumulation of follicular helper $\mathrm{T}$ cells and germinal centers. Immunity (2012) 37:880-92. doi:10.1016/j. immuni.2012.10.010

46. Deenick EK, Chan A, Ma CS, Gatto D, Schwartzberg PL, Brink R, et al. Follicular helper $\mathrm{T}$ cell differentiation requires continuous antigen presentation that is independent of unique B cell signaling. Immunity (2010) 33:241-53. doi:10.1016/j.immuni.2010.07.015

47. Baumjohann D, Preite S, Reboldi A, Ronchi F, Ansel KM, Lanzavecchia A, et al. Persistent antigen and germinal center B cells sustain $\mathrm{T}$ follicular helper cell responses and phenotype. Immunity (2013) 38:596-605. doi:10.1016/j. immuni.2012.11.020

48. Whitney JB, Hill AL, Sanisetty S, Penaloza-Macmaster P, Liu J, Shetty M, et al. Rapid seeding of the viral reservoir prior to SIV viraemia in rhesus monkeys. Nature (2014) 512(7512):74-7. doi:10.1038/nature13594

49. Deeks SG, Tracy R, Douek DC. Systemic effects of inflammation on health during chronic HIV infection. Immunity (2013) 39:633-45. doi:10.1016/j. immuni.2013.10.001

50. Lindqvist M, Van Lunzen J, Soghoian DZ, Kuhl BD, Ranasinghe S, Kranias G, et al. Expansion of HIV-specific T follicular helper cells in chronic HIV infection. J Clin Invest (2012) 122:3271-80. doi:10.1172/JCI64314

51. Locci M, Havenar-Daughton C, Landais E, Wu J, Kroenke MA, Arlehamn CL, et al. Human circulating PD-(+)1CXCR3(-)CXCR5(+) memory Tfh cells are highly functional and correlate with broadly neutralizing HIV antibody responses. Immunity (2013) 39:758-69. doi:10.1016/j.immuni. 2013.08.031

52. Boswell KL, Paris R, Boritz E, Ambrozak D, Yamamoto T, Darko S, et al. Loss of circulating CD4 T cells with B cell helper function during chronic HIV infection. PLoS Pathog (2014) 10:e1003853. doi:10.1371/journal.ppat. 1003853

53. Onabajo OO, Mattapallil JJ. Expansion or depletion of $\mathrm{T}$ follicular helper cells during HIV infection: consequences for B cell responses. Curr HIV Res (2014). doi:10.2174/1570162X12666140225153552

54. Moukambi F, Rabezanahary H, Rodrigues V, Racine G, Robitaille L, Krust B, et al. Correction: early loss of splenic Tfh Cells in SIV-infected rhesus macaques. PLoS Pathog (2016) 12:e1005393. doi:10.1371/journal. ppat.1005393 
55. Wherry EJ. T cell exhaustion. Nat Immunol (2011) 12:492-9. doi:10.1038/ ni.2035

56. Newell ML, Coovadia H, Cortina-Borja M, Rollins N, Gaillard P, Dabis F, et al. Mortality of infected and uninfected infants born to HIV-infected mothers in Africa: a pooled analysis. Lancet (2004) 364:1236-43. doi:10.1016/ S0140-6736(04)17140-7

57. Wang X, Rasmussen T, Pahar B, Poonia B, Alvarez X, Lackner AA, et al. Massive infection and loss of CD4+ $\mathrm{T}$ cells occurs in the intestinal tract of neonatal rhesus macaques in acute SIV infection. Blood (2007) 109:1174-81. doi:10.1182/blood-2006-04-015172

58. Chung Y, Tanaka S, Chu F, Nurieva RI, Martinez GJ, Rawal S, et al. Follicular regulatory $\mathrm{T}$ cells expressing Foxp3 and Bcl-6 suppress germinal center reactions. Nat Med (2011) 17:983-8. doi:10.1038/nm.2426

59. Linterman MA, Pierson W, Lee SK, Kallies A, Kawamoto S, Rayner TF, et al. Foxp3+ follicular regulatory T cells control the germinal center response. Nat Med (2011) 17:975-82. doi:10.1038/nm.2425

60. Wollenberg I, Agua-Doce A, Hernandez A, Almeida C, Oliveira VG, Faro J, et al. Regulation of the germinal center reaction by Foxp3+ follicular regulatory T cells. J Immunol (2011) 187:4553-60. doi:10.4049/jimmunol.1101328
61. Blackburn MJ, Zhong-Min M, Caccuri F, Mckinnon K, Schifanella L, Guan Y, et al. Regulatory and helper follicular T cells and antibody avidity to simian immunodeficiency virus glycoprotein 120. J Immunol (2015) 195:3227-36. doi:10.4049/jimmunol.1402699

62. Miles B, Miller SM, Folkvord JM, Kimball A, Chamanian M, Meditz $\mathrm{AL}$, et al. Follicular regulatory $\mathrm{T}$ cells impair follicular $\mathrm{T}$ helper cells in HIV and SIV infection. Nat Commun (2015) 6:8608. doi:10.1038/ ncomms 9608

Conflict of Interest Statement: The authors declare that the research was conducted in the absence of any commercial or financial relationships that could be construed as a potential conflict of interest.

Copyright (c) 2016 Wang, Ziani and Xu. This is an open-access article distributed under the terms of the Creative Commons Attribution License (CC BY). The use, distribution or reproduction in other forums is permitted, provided the original author(s) or licensor are credited and that the original publication in this journal is cited, in accordance with accepted academic practice. No use, distribution or reproduction is permitted which does not comply with these terms. 